\title{
Implementation of the School Literacy Movement through Indonesian Language Learning in High Schools during the Covid-19 Pandemic
}

\author{
Riznawati Imma Aryanti, Sarwiji Suwandi, Sumarwati
}

Postgraduate Program of Indonesian Language Education, Sebelas Maret University, Surakarta, Indonesia

Received: 25 Sep 2021; Received in revised form: 07 Nov 2021; Accepted: 13 Nov 2021; Available online: 19 Nov 2021

(C)2021 The Author(s). Published by Infogain Publication. This is an open access article under the CC BY license (https://creativecommons.org/licenses/by/4.0/).

\begin{abstract}
The School Literacy Movement (GLS) is an Indonesian government program that has been implemented since the implementation of the Revised 2013 Curriculum. The purpose of the GLS program is to shape students' character. This research aims to describe and explain 1) the School Literacy Movement (GLS) program at SMA Negeri 1 Yogyakarta during the Covid-19 pandemic, 2) implementation of the School Literacy Movement (GLS) through learning Indonesian during the Covid-19 pandemic, and 3) obstacles faced when implementing the School Literacy Movement (GLS) ) in learning Indonesian during the Covid-19 pandemic. This research is descriptive qualitative. Data collection techniques by means of observation, interviews, and documentation. Data processing is carried out in several stages, namely data reduction, data presentation, and drawing conclusions. The results showed that 1) the School Literacy Movement (GLS) program at SMA Negeri 1 Yogyakarta in general was religious literacy activities and literacy activities in learning that were still being implemented during the Covid-19 pandemic, 2) implementation of GLS through Indonesian language learning begins with assigning students to read from home, the existence of a bill for literacy activity reports (writing resumes, book reviews), and presentation of the results of literacy activities, 3) Obstacles encountered when implementing literacy activities through Indonesian language learning, namely facilities such as conditions unstable internet network, and also limited reading materials owned by students.
\end{abstract}

Keywords-Implementation, Literacy Movement, School

\section{INTRODUCTION}

Distance learning is a policy taken by the Indonesian government to replace activities in educational institutions[1]. The government's step is to urge educational institutions not to carry out educational activities as usual. The activities are diverted into alternative activities by using technology. The transfer of this distance learning method is a form of mitigation by the Indonesian government to overcome or minimize cases of the spread of the Covid-19 virus. [2]Severe Acute Respiratory Syndrome Coronavirus 2 (SARS-Cov-2) otherwise known as Corona virus is a new virus variant that infects the human respiratory system. Therefore, it needs fast and precise handling.Various policies have been issued by the Indonesian government by imposing social distancing, physical distancing, large-scale social restrictions (PSBB), as well as eliminating activities in educational institutions (with distance learning)[3].

Distance learning is a learning system that does not take place in one room so that there is no physical interaction between teachers and students[4]. Distance learning is certainly implemented by using communication technology. The use of technology in distance learning or online there are many variances of problems that hinder the effectiveness of learning such as limited mastery of technology, inadequate facilities, limited internet access, 
and budget readiness[5].Including learning Indonesian is inseparable from various obstacles. Therefore, during the Covid-19 pandemic, every school is more focused on implementing distance or online learning processes in such a way as to be effective.However, the implementation of online Indonesian learning does not fully refer to the existing Lesson Plan (RPP) because the time is relatively short[6]. Whereas learning Indonesian has two important roles, namely increasing language mastery, and forming literacy competencies[7]. Literacy is related to language skills and refers more to the results of students' critical attitudes from information skills[8]. If this is not handled, it is feared that it will affect the weakening of students' literacy skills. This is where the role of the Indonesian language teacher is to teach and at the same time stabilize student literacy.

In addition, many programs that are usually carried out in face-to-face learning in the school environment must be passive first. One of them is the school literacy program or in a government program called the School Literacy Movement.The elimination or passivation of the School Literacy Movement (GLS) activity is based on the observations of researchers in the city of Yogyakarta, Indonesia that several schools in secondary education units, both junior and senior high schools, are active in their literacy activities.Many educational institutions are forced to take the consequences to passively literacy activities in order to focus on maximizing learning activities. However, like two blades, the elimination of literacy activities also presents another problem, namely the weakening of students' reading culture, which affects their literacy skills.

The reading culture that has been honed so far is through reading non-lesson books for 15 minutes before learning begins (School Literacy Movement program). However, these reading activities have been canceled in some schools due to the impact of the Covid-19 pandemic.Of course, this condition shows the weakening of students' interest in reading so that it has an impact on student literacy. Literacy is also related to students' lives both at home and in their environment to foster noble character[9]. It should be noted that many articles that write about the literacy of the Indonesian people are still in the low class. The literacy level of students in Indonesia is categorized as low[10].The Covid-19 pandemic is not an easy temptation for all nations. All countries including Indonesia must be able to overcome all existing problems and make this Covid-19 pandemic a challenge to be more active in finding new things (such as online education services) so that they can be ready with all possibilities.

In addition to the Covid-19 pandemic, which is a new challenge in optimizing the literacy of Indonesian students, other factors are still old challenges that are still being handled. The factor in question is the low reading culture of the Indonesian people. Low reading culture is the main cause so that the literacy of Indonesian people is inferior to other countries[11]. The cause of the low interest in reading is due to the absence of a daily routine of reading books and the ease with which the digital world is misused. Now digital is used more for watching than reading information. Of course, reading culture has shifted to watching culture.

In addition, the low interest and passion for reading is partly rooted in the strong oral tradition in Indonesian social life and thinking patterns[12]. The research conducted by Saputro produced data in the form of all school members being actively involved in implementing the school literacy movement policy. Supporting factors include the availability of supporting facilities and the role of school residents who are active in school programs. Meanwhile, the inhibiting factor for the policy of the school literacy movement is the availability of books on the value of education which are difficult to obtain.

Other research on literacy that researchers encountered by[13]which produces data that there is a positive and significant influence between the school literacy movement on reading interest and reading skills. This is where the role of the Indonesian language teacher is to grow and stabilize the literacy of students who are also affected by the Covid-19 pandemic. Based on the survey, researchers found one school that had a teacher who cared about students. The teacher referred to by the researcher is one of the Indonesian language teachers at SMA Negeri 1 Yogyakarta. It seems that the teacher is trying to promote student literacy activities through their learning. Of course, in this distance learning condition, it is not easy to implement it. The reason for the teacher trying to encourage students to regularly read books (literacy activities) is interesting to talk about. This research is motivated by the basic problems caused by the Covid-19 pandemic in the education segment in Indonesia.The focus is more like on educational activities that have been affected by the Covid-19 pandemic. The impact of the Covid-19 pandemic in the education segment, such as the School Literacy Movement (GLS) program in transferring distance or online learning methods.

This research is also expected to be a reference for other schools to implement and prevent the stagnation or passivity of the School Literacy Movement program during the Covid-19 pandemic. Whereas literacy is one of the parts that is integrated in $21^{\text {st }}$ century learning and is the most important part in an educational process[14].This is because the Covid-19 that is endemic in various countries including Indonesia affects the entire order of 
life[15]. Education is included in the aspects affected. The existence of the Covid-19 virus is a new challenge in educational institutions. All activities in educational institutions must change and adjust conditions with the aim of minimizing the spread of the Covid-19 virus. The two challenges that have been mentioned to improve literacy can be answered by Indonesian teachers who are professional and care about the literacy of their students. Therefore, in this study, we want to describe the implementation of the school literacy movement through learning Indonesian, as well as the obstacles faced in implementing these literacy activities.

\section{METHOD}

This study applies a qualitative descriptive method. This research strategy is included in the case study strategy.A case study is one of the studies that reveals a certain phenomenon or activity that is taking place in one place[16]. The data was taken at the research location of SMA Negeri 1 Yogyakarta, which is an"Exemplary" school that has graduated many quality student alumni. SMA Negeri1 Yogyakarta is in city of Yogyakarta, Indonesia. The main informants in this study were Indonesian Language Teachers, Principals, and Students.Data collection techniques were carried out through interviews, observation, and documentation. The data validity technique uses source triangulation. While the data analysis techniques include data collection, data reduction, data presentation after reduction, and drawing conclusions.

\section{RESULT AND DISCUSSION}

Several principles that can be used as a benchmark in implementing a good school literacy movement program were put forward by[17]include: development of literacy that is proper predictable, balanced, integrated with the curriculum, literacy activities carried out anytime and anywhere, development of oral culture, developing religious awareness. The following is a presentation of the research findings.

\section{School Literacy Movement Program at SMA Negeri 1 Yogyakarta}

The School Literacy Movement is an Indonesian government program to overcome low literacy levels and awaken students' reading culture[18].This low literacy indicates that the Indonesian government is making changes to meet the needs of the 21 st century. Several aspects of the strategy in developing literacy activities such as capacity of facilitators, increasing the number and variety of reading sources, expanding access to learning resources, public involvement, and governance[5].SMA Negeri 1 Yogyakarta started the School Literacy Movement program policy since 2016. In 2016 the Indonesian government urged schools to integrate the School Literacy Movement program. SMA Negeri 1 Yogyakarta is a reference school and an example for other schools. The statement was made by the principal and teachers of SMA Negeri 1 Yogyakarta.

The School Literacy Movement began with the Minister of Education and Culture Regulation Number 23 of 2016 "all schools are required to integrate school literacy" then the formal form is reading nonlesson books for 15 minutes at the beginning of learning activities. The activity went well. (Principal01)

The School Literacy Movement Program has existed since 2016. The activity consists of 15 minutes of reading in the school yard, reciting (religious literacy) is the main thing. However, during the Covid-19 pandemic, the form of activity was adjusted. (Teacher-01)

This well-run process resulted in a culture of literacy in the school environment of SMA Negeri 1 Yogyakarta. The program of activities that existed in schools before the Covid-19 outbreak was a 15-minute activity of reading non-lesson books in the school yard. 15-minute reading activities are integrated intensively every morning on Tuesdays, Wednesdays and Thursdays. The 15-minute reading activity is carried out before the first lesson begins. While on Mondays and Fridays religious literacy is held. The form of activity is reading the holy book, (recitation, cults, sermons, and others according to the religion adopted by the school community). In addition, to support basic literacy activities (15 minutes of reading), literacy and arts festivals are usually held in the framework of language month. However, due to the current conditions the Covid-19 virus has changed the order of activities in educational institutions (at schools). In the SMA Negeri 1 Yogyakarta environment, distance learning is integrated according to government instructions. Therefore, literacy activities such as reading in the school yard cannot be carried out. In addition, festivals that support literacy activities cannot be held as usual.

In addition, the facilities and infrastructure at the school support the integrity of literacy activities. School facilities such as libraries and various reading materials, reading corners, literacy boxes containing reading materials and works from students, wall magazines, the availability of an internet network that is easily accessible by all school residents. The availability of school facilities 
is evidence that the school strongly supports the government in implementing the school literacy program.

Currently, not all of the facilities available at SMA Negeri 1 Yogyakarta can be used by students. As has been said, the current conditions due to the Covid-19 pandemic make it impossible to interact directly.However, in conditions like this, we need to get up and look for solutions in tackling the impact of the Covid-19 pandemic. SMA Negeri 1 plans literacy activities through distance learning by using technology. Through the Zoom meeting platform, schools are trying to integrate activities that already exist and become the habits of school residents. As for literacy activities that are integrated, namely religious literacy. Meanwhile, 15 minutes of reading literacy activities are integrated into Indonesian language learning.

Religious literacy activities are one of the main activities of the school literacy movement program that is integrated in SMA Negeri 1 Yogyakarta. This activity has become an intensive activity which is held every Monday and Friday morning. Apart from being a main activity, religious literacy is also in accordance with the mission of SMA Negeri 1 Yogyakarta, namely:

"Develop discipline, leadership, and piety through various student activities, both in intra-school student organizations (OSIS), extracurricular activities, religious activities, and other activities rooted in national culture; Instilling exemplary values and noble character through the development of a school culture that is in accordance with religious, social, and national norms and is environmentally sound." (School document-01)

Two visions of SMA Negeri 1 Yogyakarta can be realized through the school literacy movement program. One of the activities of Indonesian culture is by embracing beliefs that come from God, by believing in and carrying out worship according to the religious beliefs held. The religious literacy activity was chosen because during the Covid-19 pandemic, the school urges students to jointly increase their faith and pray that conditions like this can be passed soon.Zoom meetings are held every Monday and Friday morning. The activity began with all school residents entering the Zoom meeting platform through the link that had been shared. Then it is divided into sections according to the class and beliefs held. The forms of religious literacy activities at SMA Negeri 1 that the researchers observed were Muslim school residents reading the holy book Al-Quran or tadarus, lectures (kultum), and prayers.Likewise for Christians, Catholics, and Hindus, their activities are reading scriptures, short sermons, and closing with prayers.
The findings of religious literacy activities observed by researchers at SMA Negeri 1 Yogyakarta are in accordance with the principles of literacy implementation proposed by [17] include: development of proper and predictable literacy, balanced, integrated with the curriculum, literacy activities carried out anytime and anywhere, development oral culture, develop religious awareness. The principle by Beers is used as the foundation for SMA Negeri 1 Yogyakarta to plan and build good and proper literacy activities according to school conditions. one of the two principles that refer to the development of principles from religious literacy activities that are implemented, namely literacy is carried out anytime and anywhere, and develops religious awareness.

The principle of literacy is carried out whenever and wherever it opens the view that the implementation of literacy is flexible according to conditions. Therefore, literacy activities (reading and writing) do not burden individuals to integrate these literacy activities.Literacy activities also have an incredibly positive impact on individuals who carry out literacy activities. Literature where individuals are capable of criticizing and finding solutions to any problems encountered. This critical attitude is what SMA Negeri 1 Yogyakarta continues to strive for in integrating literacy activities. The school hopes that by continuing to hold literacy activities (GLS), students of SMA Negeri 1 Yogyakarta have a critical attitude and character and are able to solve various problems that are often found in the surrounding environment.

Then, the principle of developing religious awareness by Beers which was developed by SMA Negeri 1 Yogyakarta is more emphasized on the diversity of religions that exist in Indonesia. Students are expected not to forget religion as a foundation when studying. Because basically science and religion go hand in hand and support each other. Students are also expected to expand their views on the diversity of religions that exist in the country as a form of stimulating tolerance between religious communities.

The findings of literacy activities implemented using the Zoom meeting platform are in line with a literacy theory by Ferguson(dalam Sutrianto et al., 2016)which states that literacy does not only focus on reading and writing, but various aspects along with technological developments are involved. Therefore, literacy is the key to prepare the seeds of human resources who are able to compete in responding to the challenges of the $21^{\text {st }}$ century. The use of technology media in this literacy activity does not only cultivate reading and writing literacy. But also develop students' technological or digital literacy by using technology for positive purposes. 


\section{Implementation of the School Literacy Movement through Indonesian Language Learning during the Covid-19 Pandemic}

The term literacy has been redefined in line with the times, starting from reading and writing, until literacy is a skill. Researchers tend to agree on the definition of literacy by[20]that literacy is a comprehensive process that begins with reading, verification, analysis, testing, evaluation, and concluding activities. Literacy is inseparable from reading and writing activities. There are more reading and writing activities in language learning, one of which is Indonesian. Learning Indonesian in the 2013 curriculum aims to form the competence and skills of students who are proficient in the language (reading, writing, watching, listening, and speaking). According to the lesson plan, Indonesian language subjects were developed from three scopes of material, namely the scope of language (knowledge of the language), the scope of literature (understanding, appreciation, response, analysis, and creation of works), and literacy (expanding language competence with various specific objectives related to reading and writing).So close literacy with language assumes that literacy is an important aspect that must be considered by Indonesian language teachers. The existence of literacy activities that are integrated through Indonesian language learning is certainly especially useful students.

Literacy activities can be integrated into the learning process in schools so that they become an inseparable part of all series of student and teacher activities[5]. Based on this opinion, many literacy activities are carried out before learning begins (reading non-lesson books for 15 minutes). Activities are integrated both in the classroom and outside the classroom according to the conditions of each school. Ministry of Education and Culture[19]instructed each subject teacher to carry out independent literacy activities in the learning process. These instructions mean that all teachers are responsible for integrating literacy in every learning process, not just Indonesian language teachers. In addition, Indonesian language teachers should also be role models for teachers of other subjects in integrating literacy activities.

During distance learning, literacy activities in learning are also different as usual. Usually, the teacher assigns students in the literacy activity bill to complete a book and then write a review of the book that has been read as a bill at the end of the semester. The following is a statement from the teacher regarding literacy activities before the Covid-19 pandemic and literacy activities during distance learning.

"Initially getting used to reading 15 minutes then there are assignments at the end of the semester in the form of works, in the form of competitions, later their works will be contested in the form of short stories, there is also a form of poetry (anthology). Then students are involved in activities by the literacy committee of the intra-school student organizations. "(Teacher-02)

"For literacy activities such as before the pandemic (reading 15 minutes of books) we did not carry out but literacy activities in Indonesian language learning encouraged students to read from home." (Teacher-03)

However, at this time literacy activities in learning Indonesian must be different. The Indonesian teacher class XI at SMA Negeri 1 Yogyakarta is trying to implement literacy activities. The finding of literacy activities being integrated into Indonesian language learning shows that literacy activities at the school are in accordance with government instructions (Fianto et al., 2018) that all subject teachers are encouraged to integrate literacy activities in every teaching and learning activity. In addition, it is also in accordance with the development of one of the principles of literacy activities by Beers, which is integrated with the curriculum and the development of proper and predictable literacy. All earlier learning activities have been planned by the teacher in the learning implementation plan (what activities and strategies the teacher chooses to carry out a learning and literacy activity). Therefore, the teacher must have considered correctly in choosing strategies and predicting the results.

The teacher's reason for continuing to implement student literacy activities is because the teacher really cares about student literacy. The teacher hopes that during the Covid-19 pandemic, students' reading culture does not weaken and must be maintained. Therefore, the teacher strives to encourage students to carry out literacy activities. The following is an excerpt of data by informants regarding the reasons and expectations in carrying out literacy activities during the Covid-19 pandemic.

"My hope is during the Covid-19 pandemic, the student literacy culture will be maintained. Therefore, as an Indonesian teacher, I try to optimize students' literacy activities (reading culture). "'(Teacher-04)

Through literacy activities, students also enhance the attitude of responsibility. The attitude of responsibility is the result of literacy activities that students make. After students finish reading the book, there is a form of bill that must be fulfilled. The bill in question is the activity of writing what things students have gotten after reading the book. The following is evidence of a quote from the teacher as an informant. 
"Through learning Indonesian subjects, we are as language teachers assign students to fill out a "literacy activity report". In this activity, students are free to read fiction and non-fiction books while at home and write down several components in the Literacy Activity Report,then once a week students submit the results of the Literacy Activity Report before learning begins." (Teacher-05)

The implementation of literacy activities by each teacher is different. This is in accordance with the situation and conditions of learning. In addition, each teacher has a distinct perspective and strategy when educating students. One of the Indonesian language teachers at SMA Negeri 1 Yogyakarta is trying to integrate literacy activities through his learning during the COVID-19 pandemic. The teacher's strategy for integrating literacy activities is by assigning students to read books from home. During reading activities, students must report the progress of their reading results through the Google Classroom platform.

"If in my learning, students are assigned to read books outside of class (in their own homes), I always remind them through WhatsApp Groups and in Google Classroom. I can check the extent of the student literacy process through Google classroom and Google Doc. During class, I start with a report on the results of student literacy activities (students present their readings) and so on." (Teacher-06)

"I observe the student literacy process through Google Classroom, Ms. Students also collect reports on their activities (title of book, number of pages, and what resumes have been read). If students have uploaded reports on literacy activities, I can immediately monitor and assess how far the student literacy reports have been." (Teacher-07)

The quote above describes how teachers can check students so that literacy activities are not just a teacher's task to students. This implemented literacy activity requires students' responsibility in carrying out their literacy activities. The principles of literacy activities by Beers developed by teachers are literacy activities carried out anytime and anywhere, and the development of oral culture.

The literacy activity developed based on Beers' principle "literacy is carried out anywhere and anytime" is clear in the activities of students reading from their respective homes. If literacy activities are usually carried out at school, now students are doing literacy from their homes. Utilizing a variety of readings that are around the house, makes students appreciate time better.This is because students can do literacy (reading) in their spare time so that no time is wasted. This home literacy activity also has a positive impact because parents also take part in checking all their children's learning activities.

Then on another principle that is proper and used as a benchmark for teachers in developing literacy activities is the development of oral culture. This is found when students present or report their readings to the teacher and their peers at the beginning of the lesson. The presentation of the results of this literacy activity by students encourages students to be proficient in language (speaking) or students who are communicators.

\section{Constraints faced in implementing the School Literacy Movement through Indonesian language learning}

Findings of obstacles faced by schools were obtained from informants. Just like the general conditions that occur, the obstacles faced in integrating literacy activities are in line with the obstacles when learning activities take place. Learning Indonesian in the Covid-19 pandemic era includes several things including facilities and infrastructure, reading sources or books, and student conditions[21]. The obstacles that are generally encountered when literacy activities are implemented by schools are facilities, time, reading materials, and funding. The obstacle that is often faced when implementing literacy activities in Indonesian language learning is the facilities. More precisely on the condition of an unstable internet network. It is proven in the quote by the teacher informant as follows.

"The same obstacle when carrying out distance learning is that the internet network is less stable." (Teacher-08)

Unstable network constraints when using Google Meeting platform can be overcome by mutating to the WhatsApp Group platform. In addition, the constraints on students' reading materials are limited. Students said that they only read what they had, while buying them was limited to the government's policy of social distancing. So, students read the reading material as it is. However, the teacher can overcome these obstacles by freeing students to read whatever is around the student environment, which students enjoy such as comics, newspapers, magazines and so on.

However, the existence of literacy activities that have become entrenched in SMA Negeri 1 Yogyakarta makes the obstacle an understandable thing and not a big problem. Literacy (reading) has become a student need, so students do it with enthusiasm. The Covid-19 pandemic is both a challenge and an opportunity.Covid-19 is a deep challenge for educational institutions to choose the right policy by conducting distance learning. Covid-19 is also 
an opportunity because if it does not happen, the use of technology will not be used optimally. So that schools can directly practice various platforms for learning. The principle of literacy activities by Beers "literacy activities wherever and whenever" can be developed by teachers very well.

\section{CONCLUSION}

Based on the results of the research and discussion that have been presented, the following conclusions can be presented.

1) The School Literacy Movement Program at SMA Negeri 1 Yogyakarta is implemented a) in general by all school members in religious literacy and b) integrated into Indonesian language learning.

2) The implementation of literacy activities in learning Indonesian is based on the Beers literacy principle and the teacher develops it well. Starting with assigning students to read from home, the task of reporting on literacy activities (writing resumes, book reviews), and presenting the results of literacy activities (language skills).

3) Constraints faced when implementing literacy activities through Indonesian language learning are facilities such as unstable internet network conditions, and limited reading materials owned by students.

The Covid-19 pandemic has created new challenges for educational institutions. So, the government took a new policy to deal with it. However, the Covid-19 pandemic is also an opportunity for us to try new steps to develop what has never been tried.For example, in the discussion of this research, the government's steps to use platform technology for distance learning policies is a new step in responding to new and old challenges (the Covid-19 pandemic and industry 4.0). If the Covid-19 pandemic does not appear, we do not know when we can practice distance learning in the current era.

\section{REFERENCES}

[1] A. Abidah, H. N. Hidaayatullaah, R. M. Simamora, D. Fehabutar, and L. Mutakinati, "The Impact of Covid-19 to Indonesian Education and Its Relation to the Philosophy of 'Merdeka Belajar,"' Stud. Philos. Sci. Educ., vol. 1, no. 1, pp. 38-49, 2020, doi: 10.46627/sipose.v1i1.9.

[2] I. Wahidah, R. Athallah, N. F. S. Hartono, M. C. A. Rafqie, and M. A. Septiadi, "Pandemik COVID-19: Analisis Perencanaan Pemerintah dan Masyarakat dalam Berbagai Upaya Pencegahan," J. Manaj. dan Organ., vol. 11, no. 3, pp. 179-188, 2020, doi: 10.29244/jmo.v11i3.31695.
[3] L. D. Herliandry, N. Nurhasanah, M. E. Suban, and H. Kuswanto, "Pembelajaran Pada Masa Pandemi Covid-19," JTP - J. Teknol. Pendidik., vol. 22, no. 1, pp. 65-70, 2020, doi: $10.21009 /$ jtp.v22i1.15286.

[4] A. Irhandayaningsih, "Pengukuran literasi digital pada peserta pembelajaran daring di masa pandemi covid-19," Anuva, vol. 4, no. 2, pp. 231-240, 2020.

[5] Atmazaki, N. B. V. Ali, W. Muldian, Miftahussururi, M. N. Nento, and Q. S. Akbari, Panduan Gerakan Literasi Nasional. Jakarta: Kementerian Pendidikan dan Kebudayaan, 2017.

[6] S. S. Nusantari, Sumarwati, and A. Anindyarini, "Pembelajaran Bahasa Indonesia Secara Online pada Masa Pandemi Covid-19 di SMA Islam Terpadu Nur Hidayah Sukoharjo," Basastra J. Bahasa, Sastra, Pengajarannya, vol. 8, no. 2, pp. 206-214, 2020.

[7] H. Subandiyah, "Pembelajaran Literasi Dalam Mata Pelajaran Bahasa Indonesia," Paramasastra, vol. 2, no. 1, pp. 111-123, 2017, doi: 10.26740/parama.v2i1.1502.

[8] A. Joyo, "Gerakkan Literasi dalam Pembelajaran Bahasa Indonesia Berbasis Kearifan Lokal Menuju Siswa Berkarakter," J. KIBASP (Kajian Bahasa, Sastra dan Pengajaran), vol. 1, no. 2, pp. 159-170, 2018, [Online]. Available:

https://media.neliti.com/media/publications/256081gerakan-literasi-dalam-pembelajaran-baha-dc455f80.pdf.

[9] J. Alfin, "Membangun Budaya Literasi dalam Pembelajaran Bahasa Indonesia Menghadapai Era Revolusi Industri 4.0," Pentas J. Ilm. Pendidik. Bhs. dan Sastra Indones., vol. 4, no. 2, pp. 60-66, 2018, [Online]. Available: https://jurnal.univpgripalembang.ac.id/index.php/Prosidingpps/article/view/2511.

[10] U. Khaira, M. Harun, and R. Bahry, "Reading Habits, Interests, And Reading Comprehension Of Students In Schools Implementing School Literacy Movement," $J$. Educ. Sci. Technol., vol. 5, no. 3, pp. 230-238, 2019, doi: 10.26858/est.v5i3.10211.

[11] S. Rohman, "Membangun Budaya Membaca Pada Anak Melalui Program Gerakan Literasi Sekolah," J. Pendidik. dan Pembelajaran Dasar, vol. 4, no. 1, pp. 156-160, 2017.

[12] A. S. Saputro, "Implementasi Kebijakan Gerakan Literasi Sekolah di SMA Negeri 2 Bantul," J. Kebijak. Pendidik., vol. VI, no. 3, pp. 319-330, 2017.

[13] T. Wulandari and Haryadi, "Pengaruh Gerakan Literasi Sekolah Terhadap Minat Baca Dan Keterampilan Membaca Siswa SMA N 1 Purworejo," J. Pendidik. Bhs. dan Sastra Indones., vol. 2, no. 9, pp. 92-97, 2020.

[14] P. Sutanto, Panduan Implementasi Kecakapan Abad 21 Kurikulum 2013 di SMA. Kementerian Pendidikan dan Kebudayaan, 2017.

[15] R. D. Astuti, A. Andayani, and S. Suyitno, "Implementation of Learning to Write News Text via the Internet in the COVID-19 Pandemic Era (Case Study in Class VIII MTs N 1 Surakarta)," Int. J. Multicult. Multireligious Underst., vol. 8, no. 2, p. 206, 2021, doi: 10.18415/ijmmu.v8i2.2335.

[16] R. K. Yin, Case Study Research and Applications Design and Methods, Sixth Edit. Los Angeles: SAGE, 2018.

[17] C. S. Beers EdD, J. W. Beers, and J. O. Smith EdD, A 
Principal's Guide to Literacy Instruction (Tools for Teaching Literacy). New York: London: The Guilford Press, 2010.

[18] I. N. Elita and A. Supriyanto, "Peningkatan Minat Baca Peserta Didik Melalui Gerakan Literasi Sekolah," in Seminar Nasional - Jurusan Administrasi Pendidikan Fakultas Ilmu PEndidikan Universitas Negeri Malang, 2019, pp. 106-113.

[19] Sutrianto, N. Rahmawan, S. Hadi, and H. Fitriono, Panduan Gerakan Literasi Sekolah Di Sekolah Menengah Atas. Jakarta Selatan: Direktorat Jenderal Pendidikan Dasar dan Menengah Kementerian Pendidikan dan Kebudayaan, 2016.

[20] F. Fianto et al., Bunga Rampai GLS Praktik Baik Pembelajaran dan Penumbuhan Budaya Literasi. Jakarta: Direktorat Jenderal Pendidikan Dasar dan Menengah Kementerian Pendidikan dan Kebudayaan, 2018.

[21] Y. Prihatin and R. H. Sari, "Problematika Pembelajaran Bahasa Indonesia Di Era Pandemi Covid-19," J. Pendidik. Tambusai, vol. 5, no. 2, pp. 4537-4546, 2021, doi: 10.35316/edupedia.v3i2.251. 